\title{
Analisa Postur Kerja Pekerja Pengupas Mete Dengan REBA(Rapid Entire Body Assessment)
}

\author{
Anny Maryani, Sri Gunani Partiwi, Diyah Ayu Ratnasanti \\ Jurusan Teknik Industri, Fakultas Teknologi Industri, Institut Teknologi Sepuluh Nopember (ITS) Surabaya \\ annymaryani@ie.its.ac.id
}

\begin{abstract}
Abstrak
Proses pengupasan mete dan pengeluaran biji mete dilakukan secara manual. Biji mete dikupas satu persatu dengan menggunakan kacip, kemudian dikuluarkan dari cangkangnya menggunakan cukit. Stasiun kerja pengupas mete sangat segerhana. Umumnya mereka bekerja dengan duduk di kursi rendah, hanya beberapa yang bekerja pada kursi yang agak tinggi. Selama proses pengupasan ini terdapat keluhan dari pekerja mengenai rasa sakit pada beberapa bagian tubuh akibat proses pengupasan mete. Keluhan fisik yang dialami berupa rasa sakit ini terjadi pada jaringan musculoskeletal (musculoskeletal tissue). Didapati bahwa proses kerja yang tidak ergonomis dan alat yang sifatnya manual (kacip dan cukit) diduga menjadi penyebab keluhan fisik tersebut. Pada penelitian ini dilakukan pengamatan postur kerja untuk menilai risiko dan keluhan muskuloskeletal (musculoskeltal disorders) yang dialami anggota tubuh dikarenakan posisi kerja yang tidak ergonomis. Metode yang digunakan adalah REBA (Rapid Entire Body Assessment). Ditentukan dua jenis operasi kerja yaitu mengupas mete dan mengeluarkan biji mete yang diamati pada tiga orang pekerja. Hasil penilaian REBA diketahui bahwa posisi kerja mengupas mete berada pada skor 12-14 dan mengeluarkan mete berada pada skor 13. Skor ini menunjukkantingkat aksi 4 yang artinya risiko pekerjaan sangat tinggi sehingga perlu segera diberikan tindakan perbaikan. Tindakan perbaikan yang nantinya dilakukan adalah perbaikan metode kerja yang dapat mengurangi risiko pada badan, leher, kaki, lengan atas, lengan bawah dan pergelangan tangan.
\end{abstract}

Kata kunci: ergonomis, musculoskeletal disorders, pengupas mete, posisi kerja, REBA (Rapid Entire Body Assessment)

\section{PENDAHULUAN}

Desa Badas Kecamatan Pare Kabupaten Kediri merupakan salah satu desa di Jawa Timur yang memiliki usaha pengelolaan mete mulai dari gelondongan mete menjadi produk kacang mete OC. Proses produksi dilakukan oleh usaha rumahan yang berkelompok dan dikelola oleh KSM. Desa Badas tidak menghasilkan buah Jambu Mete, namun mendatangkan bahan baku gelondongan mete untuk dikupas. Di Desa Badas terdapat sekitar 120 orang pengupas mete yang dinaungi oleh 20 kelompok tani dan dikelola Kelompok Swadaya Masyarakat (KSM). Salah satu KSM yang ada di Desa Badas adalah Mente Yosky yang dikelola oleh Bapak Mulyono.

Permintaan yang masuk ke UKM Mente Yosky selanjutnya didistribusikan kepada pengupas rumahan dalam bentuk gelondongan karung seberat $25 \mathrm{~kg}$. Kemudian pengupas secara berkelompok memulai proses produksi mete sampai menghasilkan biji mete siap jual. Setiap satu gelondongan mete menghasilkan sekitar 6,4 produk kacang mete atau disebut produk OC. Permintaan yang masuk ke Mente Yosky bersifat fluktuatif dalam jumlah yang besar. Pada tahun 2015 berhasil didatangkan 150 gelondong mete yang harus diselesaikan dalam waktu 1 minggu. Kondisi ini menyebabkan pekerja bekerja melebihi jam kerja normal dikarenakan target waktu.

Proses pengupasan mete dilakukan secara manual dengan menggunakan alat yang sederhana yaitu kacip. Biji mete dikupas satu persatu dengan menggunakan kacip. Stasiun kerja pengupas mete sangat segerhana. Umumnya mereka bekerja dengan duduk di kursi rendah, hanya beberapa yang bekerja pada kursi yang agak tinggi. Selama proses pengupasan ini terdapat keluhan dari pekerja mengenai rasa sakit pada beberapa bagian tubuh akibat proses pengupasan mete. Keluhan fisik yang dialami berupa rasa sakit ini terjadi pada jaringan musculoskeletal (musculoskeletal tissue). Didapati bahwa proses kerja yang tidak ergonomis dan alat yang sifatnya manual (kacip dan cukit) diduga menjadi penyebab keluhan fisik tersebut. Berkaitan dengan proses yang manual ini dan keluhan rasa sakit ini, belum ada penelitian yang dilakukan untuk menganalisa beban yang terjadi pada bagian tubuh, misalnya leher, punggung, lengan atas, lengan bawah maupun kaki.

Widanarko dkk, 2011 menyatakan bahwa berbagai penelitian telah dilakukan pada topik musculoskeletal tissue, misalnya mengenai ‘impairment/pelemahan' [1], [2] ‘disorders/gangguan' [3], [4] [5]or 'injuries/cedera' [6], [7], 'pain/rasa sakit' [8]-[10] 'discomfort/ketidaknyamanan' [11], [12] and 'symptoms/gejala' [13].

Oleh karena itu perlu dilakukan penelitian lebih lanjut untuk mengkonfirmasi dugaan. Sementara itu belum pernah dilakukan penilaian aspek ergonomis dan metode kerja pada pengupas mete di Desa Badas. Pada penelitian ini dilakukan analisa postur kerja pengupas mete untuk mendapatkan penilaian tingkat bahaya yang ada. Metode yang digunakan adalah 
REBA (Rapid Entire Body Assessment). REBA merupakan (1) alat yang sistematis untuk cepat menilai risiko dari postur, kekuatan dan pengulangan, (2) dapat digunakan untuk engurangi skor melalui tugas desain ulang dan/atau bimbingan perilaku, dan (3) penilaian ulang setelah perbaikan.

\section{TINJAUAN PUSTAKA}

Pada bagian ini dijelaskan mengenai tinjauan pustaka yang mendukung pelaksanaan penelitian. Diantaranya adalah musculoskeletal disorders (MSDs), REBA (Rapid Entire Body Assessment), dan proses produksi mete di Desa Badas

\subsection{Musculoskeletal Disorders (MSDs)}

Punnet dan Wegman (2004) menyatakan bahwa musculoskeletal disroders (MSDs) meliputi berbagai kondisi inflamasi dan degeneratif yang mempengaruhi otot-otot, tendon, ligamen, sendi, saraf perifer, dan mendukung pembuluh darah. Kondisi ini termasuk sindrom klinis seperti radang tendon dan kondisi yang terkait (tenosynovitis, epicondylitis, bursitis), gangguan kompresi saraf (carpal tunnel syndrome, linu panggul), dan osteoarhrosis, serta kondisi kurang standar seperti pada mialgia, nyeri pinggang dan reginal daerah lainnya dengan kondisi sindrom nyeri disebabkan patologi yang dikenal. Daerah tubuh yang paling sering terkena adalah punggung, leher, bahu, lengan, dan tangan, meskipun baru-baru ekstremitas bawah telah mendapat perhatian lebih. Data yang akurat tentang insiden dan prevalensi muskuloskeletal disroders sulit untuk dibandingkan antar negara. Namun demikian, MSDs adalah kategori terbesar dari penyakit yang berhubungan dengan pekerjaan, mewakili sepertiga atau lebih dari semua penyakit akibat kerja yang terdaftar di AS, negara Nordik, dan Jepang [14].

Devereux et al, 2004 menyatakan bahwa ada hubungan antara tekanan kerja (job stress) dengan keluhan muskuloskeletal (muculoskeletal complaint). Hubungan tersebut digambarkan pada gambar 1 :

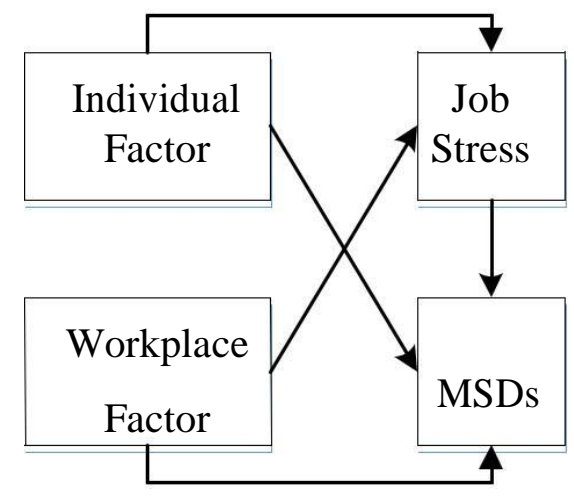

Gambar 1 Faktor yang mempengaruhi MSDs

\subsection{REBA (Rapid Entire Body Assessment)}

Analisis postural dapat menjadi teknik yang kuat untuk menilai aktivitas kerja. Risiko cedera muskuloskeletal terkait dengan postur yang tercatat, dalam konteks penilaian kerja ergonomis penuh, dapat menjadi faktor utama untuk mengimplementasikan perubahan [15]. Salah satu metode analisa postur kerja adalah REBA yang dikembangkan oleh Hignett, 1998 serta McAtamney dan Hignett, 1995.

Tujuan dari penggunaan REBA adalah (1) mengembangkan sistem analisis postural sensitif terhadap risiko muskuloskeletal dalam berbagai tugas, (2) membagi tubuh menjadi segmen yang akan dikodekan secara individual, dengan mengacu pada pesawat gerakan, (3) menyediakan sistem scoring untuk aktivitas otot yang disebabkan oleh statis, dinamis, perubahan yang cepat atau postur yang tidak stabil, (4) mencerminkan kopling yang penting dalam penanganan beban tetapi tidak selalu melalui tangan, (5) memberikan tingkat tindakan dengan indikasi mendesak, serta (6) merupakan metode analisa yang sederhana.

Metode REBA melakukan penilaian postur kerja pada dua kategori. Kategori A menilai trunk (badan), neck (leher) dan legs (kaki). Sedangkan Kategori B menilai upper arms (lengan atas), lower arms (lengan bawah) dan wrists (pergelagan tangan). Nilai dari kedua kategori tersebut dijadikan satu pada Tabel $\mathrm{C}$ yang akan memberikan penilaian akhir dan menyatakan tingkat risiko dari postur yang dinilai.

\subsection{Kondisi Saat ini Proses Produksi Mete}

Proses produksi Mete di Desa Badas saat ini dilakukan dengan cara manual. Terdapat delapan operasi dan satu inspeksi untuk proses poduksi mete. Penjelasan untuk proses produksi mete adalah sebagai berikut :

1. O-1 : Pemilihan gelondongan mete

Kriteria pemilihan gelondongan mete adalah besaran biji, tidak berbintik, tidak keriput, tidak busuk, dan berisi. Pemilihan dilakukan menggunakan tampah.

2. O-2 : Penjemuran gelondongan mete 
3. Proses penjemuran gelondongan dilakukan untuk mengurangi getah dalam cangkang, sehingga dihasilkan gelondongan mete yang benar-benar kering. Penjemuran dilakukan 1-2 hari pada tampah, tergantung kualitas gelondongan yang didapatkan.

4. O-3 : Pengupasan cangkang mete

Saat ini proses pengupasan dilakukan secara manual dengan menggunakan kacip sederhana. Dengan menggunakan alat ini belum secara optimal menghasilkan kacang bermutu baik, prosentasi kacang pecah dan belah masih cukup tinggi.

5. O-4 : Pengeluaran biji mete

Alat yang digunakan adalah alat pencukit kecil yang bekerja melepaskan seluruh bagian mete dari kulit cangkangnya. Proses dilakukan satu per satu.

6. O-5 : Pengeringan biji mete

Pengeringan dilakukan selama 2-3 jam untuk mendapatkan kondisi yang minim kadar air.

7. O-6 : Penyangraian biji mete

Proses penyangraian di atas wajan datar dengan menggunakan pasir.

8. O-7 : Pengupasan kulit ari

Pengupasan kulit ari dilakukan dengan menggunakan pisau segera setelah proses penyangraian.

9. O-8 : Pengeringan mete kupas

Kacang mete yang telah dikupas arinya di keringkan kembali untuk meningkatkan ketahanan dalam penyimpanan.

10. I-1 : Inspeksi kualitas mete

Setelah kering kacang mete disortir, dipisahkan kacang mete yang berwarna kehitaman karena kecambah, kacang mete yang tidak utuh dan utuh.

\section{METODE PENELITIAN}

Analisa postur kerja yang dilakukan melalu beberapa tahapan, yaitu :

1. Menentukan operasi kerja yang akan diamati, yaitu operasi pengupasan cangkang mete dan pengeluaran biji mete.

2. Menentukan pekerja yang akan diamati. Pada pelaksanaan penelitian ini dilakukan pengamatan pada tiga orang pekerja.

3. Menngamati postur kerja yang dilakukan pekerja, seperti yang ditunjukkan gambar 2.

4. Melakukan penilaian pada masing-masing bagian tubuh sesuai dengan table REBA dengan terlebih dahulu menentukan sudut dan coupling.

5. Mendapatka hasil penilaian dan melakukan analisa.

6. Memberikan usulan perbaikan yang dapat diterapkan.
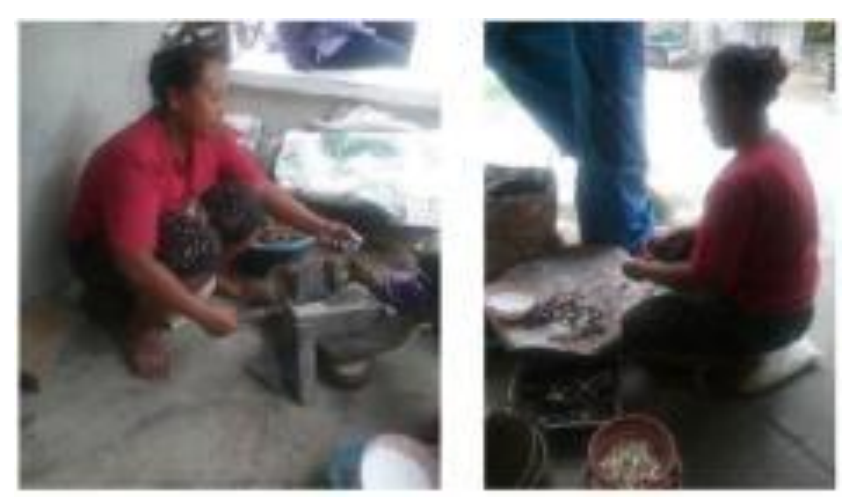

Gambar 2 Postur kerja yang diamati

\section{HASIL DAN PEMBAHASAN}

Penilain postur kerja dilakukan dengan menggunakan metode REBA untuk dua posisi yaitu posisi kerja mengupas dengan menggunakan kacip dan mengeluarkan mete dengan menggunakan cukit. Penilaian REBA dilakukan dengan menggunakan perhitungan otomatis di excel. Gambar 3 menunjukkan contoh hasil penilaian postur tubuh menggunakan REBA. Pada pekerja 1 penilai yang dilakukan adalah:

1. Trunk/badan dinilai 4 yaitu pada posisi badan membungkuk fleksi $>60^{\circ}$.

2. Neck/leher dinilai 3 yaitu pada posisi leher fleksi atau ekstensi $>20^{\circ}$ sekaligus membungkuk dana tau memuntir secara lateral.

3. Legs/kaki dinilai 1 yaitu pada posisi kedua kaki tertopang dengan baik di lantai dalam keadaan duduk.

4. Upper arms/lengan atas dinilai 4 yaitu pada posisi lengan flekasi antara $46^{\circ}-90^{\circ}$ dan lengan diangkat menjauhi badan.

5. Lower arms/lengan bawah dinilai 2 yaiu pada posisi lengan bawah fleksi antara $<60^{\circ}$

6. Wrist/pergelangan tangan dinilai 3 yaitu pada posisi pergelangan tangan fleksi/ekstensi $>15^{\circ}$.

7. Load/force/beban dinilai 2 yaitu $>10 \mathrm{~kg}$.

8. Coupling/jenis pegangan dinilai 2 yaitu pegangan kurang baik untuk digunakan

9. Activity/aktivitas otot dinilai 2 yaitu satu tangan pada posisi statis dan mengerjakan pekerjaan berulang-ulang. 


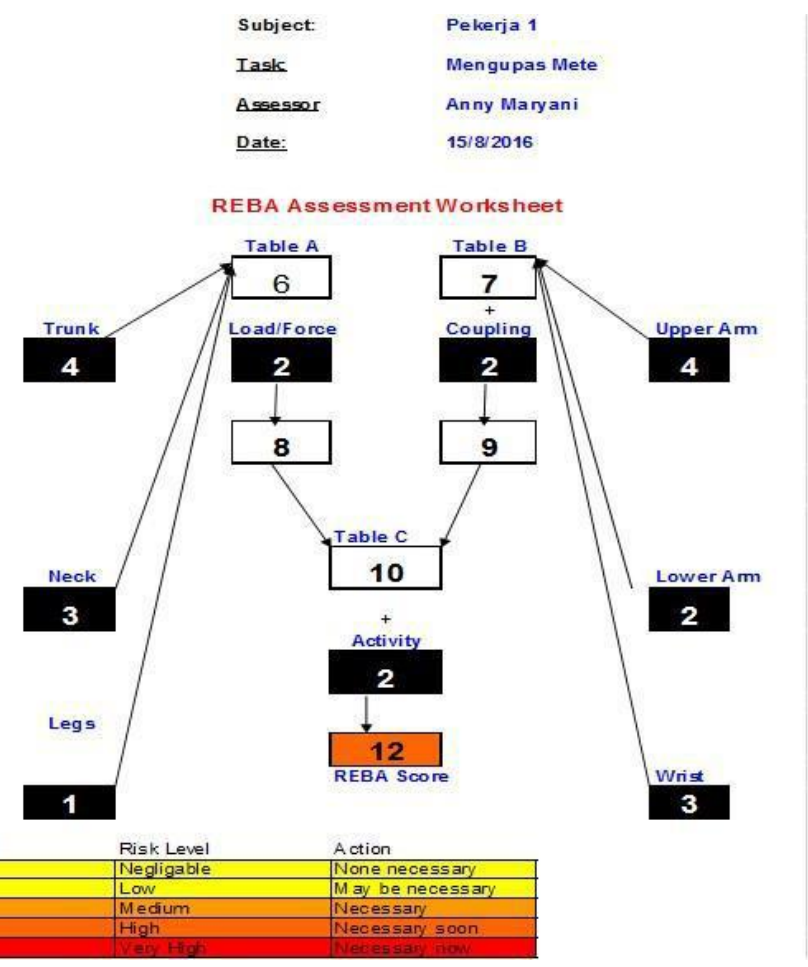

Gambar 3 Penilaian REBA mengupas mete Pekerja 1

Penilaian yang sama juga dilakukan pada pekerja 2 dan 3 serta posisi kerja mengeluarkan biji mete.

Table 1 menunjukkan hasil penilaian REBA secara keseluruhan.

\begin{tabular}{|c|c|c|c|c|c|c|}
\hline No & Nama Aktivitas & \# Pekerja & $\begin{array}{l}\text { Skor } \\
\text { Akhir }\end{array}$ & $\begin{array}{c}\text { Tingkat } \\
\text { Aksi }\end{array}$ & $\begin{array}{l}\text { Tingkat } \\
\text { Risiko } \\
\end{array}$ & Tindakan \\
\hline \multirow{3}{*}{1} & \multirow{3}{*}{ Mengupas mete } & Pekerja 1 & 12 & \multirow{6}{*}{4} & \multirow{6}{*}{$\begin{array}{l}\text { Sangat } \\
\text { Tinggi }\end{array}$} & \multirow{6}{*}{ Diperlukan tindakan sesegera mungkin } \\
\hline & & Pekerja 2 & 13 & & & \\
\hline & & Pekerja 3 & 14 & & & \\
\hline \multirow{3}{*}{2} & \multirow{3}{*}{$\begin{array}{l}\text { Megeluarakan } \\
\text { mete }\end{array}$} & Pekerja 1 & 13 & & & \\
\hline & & & & & & \\
\hline & & Pekerja 3 & 13 & & & \\
\hline
\end{tabular}

Berdasarkan hasil penilaian REBA didapatkan bahwa kedua posisi dan ketiga pekerja yang diamati memiliki tingkat aksi 4 yaitu risiko tinggi dan memerlukan tindakan perbaikan sesegera mungkin. Perbaikan yang diusulkan akan meliputi aspek perbaikan metode kerja dan juga penerapan teknologi tepat guna untuk mengurangi keluhan fisik pekerja dan meningkatkan produktivitas. Usulan yang diajukan adalah memperbaiki stasiun kerja dengan menjadikan pekerja bekerja pada posisi duduk di atas kursi dan alat kupas berada di meja. Usulan selanjutnya adalah menciptakan inovasi alat kupas yang ergonomis dan dapat digunakan dengan energi yang minimal, sehingga dapat mengurangi keluhan fisik pekerja. Kedua usulan tersebut akan ditindaklanjuti pada penelitian berikutnya.

\section{KESIMPULAN}

Kesimpulan yang diambil dari pelaksanaan penelitian ini adalah bahwa keluhan fisik yang dialami pekerja pengupas mete pada jaringan musculoskeletal (musculoskeletal tissue) dialami karena posisi kerja dan stasiun kerja yang tidak ergonomis. Penilaian postur kerja dengan menggunakan metode REBA dilakukan pada dua operasi kerja yaitu mengupas mete dengan kacip dan mengeluarkan biji mete dengan cukit. Alat sederhana yang digunakan juga menyebabkan keluhan fisik pada pergelangan tangan. Tiga orang pekerja dipilih untuk dinilai postur tubuhnya dengan REBA. Berdasarkan penilaian yang dilakukan didapatkan bahwa operasi kerja mengupas mete berada pada skor 12-14 dan mengeluarkan biji mete berada pada skor 13. Kedua operasi ini berada pada tingkat aksi 4 dengan risiko kerja yang sangat tinggi, sehingga perlu tindakan perbaikan sesegera mungkin.

Usulan perbaikan diajukan untuk ditindaklanjuti pada penelitian selanjutnya. Usulan tersebut adalah adalah memperbaiki stasiun kerja dengan menjadikan pekerja bekejra pada posisi duduk di atas kursi dan alat kupas berada di meja. Usulan selanjutnya adalah menciptakan inovasi alat kupas yang ergonomis dan dapat digunakan dengan energi yang minimal, sehingga dapat mengurangi keluhan fisik pekerja. 


\section{DAFTAR PUSTAKA}

[1] J. L. Cunningham, L.S. Kelsey, "Epidemiology of musculoskeletal impairments and associated disability," Am. $J$. Public Health, vol. 74, pp. 574-579, 1984.

[2] M. C. Kelsey, J.L. Hochberg, "Epidemiology of Chronic Musculoskeletal Disorders.," Annual Review of Public Health, pp. 379-401, 1988.

[3] R. B. M. Hartman, E. Oude Vrielink, H.H.E. Metz, J.H.M. Huirne, "Exposure to physical risk factors in Dutch agriculture: effect on sick leave due to musculoskeletal disorders.," Int. J. Ind. Ergon., vol. 35, pp. 1031-1045, 2005.

[4] F. Lawrence, R.C. Helmick, C.G. Arnett, F.C. Deyo, R.A. Felson, D.T. Giannini, E.H. Heyse, S.P. Hirsch, R. Hochherg, M.C. Hundek, G.G. Liang, M.H. Yillemer, S.R. Steen, V.D. Wolfe, "Estimates of the prevalence of arthritis and selected musculoskeletal disorders in the United States.," Arthritis Rheum., vol. 41, pp. 788-799, 1998.

[5] J. Østensvik, T. Veiersted, K.B. Cuchet, E. Nilsen, P. Hanse, J.J. Carlzon, C. Winkel, “. A search for risk factors of upper extremity disorders among forest machine operators: a comparison between France and Norway," Int. J. Ind. Ergon., vol. 38, pp. 1017-1027, 2008.

[6] N. . Gardner, L.I. Landsittel, D.P. Nelson, "Risk factors for back injury in 31,076 retail merchandise store workers,” Am. J. Epidemiol., vol. 825-833, 1999.

[7] K. Tappin, D.C. Bentley, T.A. Vitalis, A. Macky, “An analysis of sprain and strain injury data for the New Zealand meat processing industry from national and industry injury surveillance databases," Ergonomics, vol. 51, pp. 17211734, 2008.

[8] C. Andersson, H.I. Ejlertsson, G. Leden, I. Rsenberg, "Chronic pain in a Geographically defined general population: studies of differences in age, gender, social Class, and pain Localization," Clin. J. Pain, vol. 9, pp. 174-184, 1993.

[9] M. Okunribido, O.O. Magnusson, M. Pope, "Delivery drivers and low-back pain: a study of the exposures to posture demands, manual materials handling and whole-body vibration,” Int. J. Ind. Ergon., vol. 36, pp. 265-273, 2006.

[10] P. J. Walker, "Strength and erosion characteristics of earth blocks and earth block masonry," J. Mater. Civ. Eng., vol. 16, no. 5, pp. 497-506, 2004.

[11] R. Dykes, "Prevalence of Musculoskeletal Discomfort in Seventy Three Primary and Secondary School Teachers in New Zealand," Massey University, 2009.

[12] S. . Palliser, C.R. Firth, H.M. Feyer, A.M. Paulin, "Musculoskeletal discomfort and work-related stress in New Zealand dentists.,"Work Stress, vol. 19, pp. 351-359, 2005.

[13] V. Morken, T. Moen, B. Riise, T. Bergum, O. Bua, L. Vigeland Hauge, S.H. Holien, S. Langedrag, A. Olson, H.-O. Pedersen, S. Liahjell Saue, I.L. Midttun Seljebo, G. Thoppil, "Prevalence of musculoskeletal symptoms among aluminium workers.," Occup. Med., vol. 50, no. 414-421, 2000.

[14] R. H. Sjøgaard, G. Sejersted, O.M. Winkel, J. Smolander, J. Westgaard, K. Westgaard, "Exposure assessment and mechanisms of pathogenesis in work-related musculoskeletal disorders: significant aspects in the documentation of risk factors.," in Johanesen, S. Johanses (Eds), Work and health: Scientific basis of progress in the working environmen, 1993, pp. 22-25.

[15] L. Hignett, S. McAtamney, “Rapid Entire Body Assessment (REBA),” Appl. Ergon., vol. 31, pp. 201-205, 2000. 